\title{
WHO ARE YOU?: INTERSECTIONALITY IN THE ACADEMIC LIBRARY
}

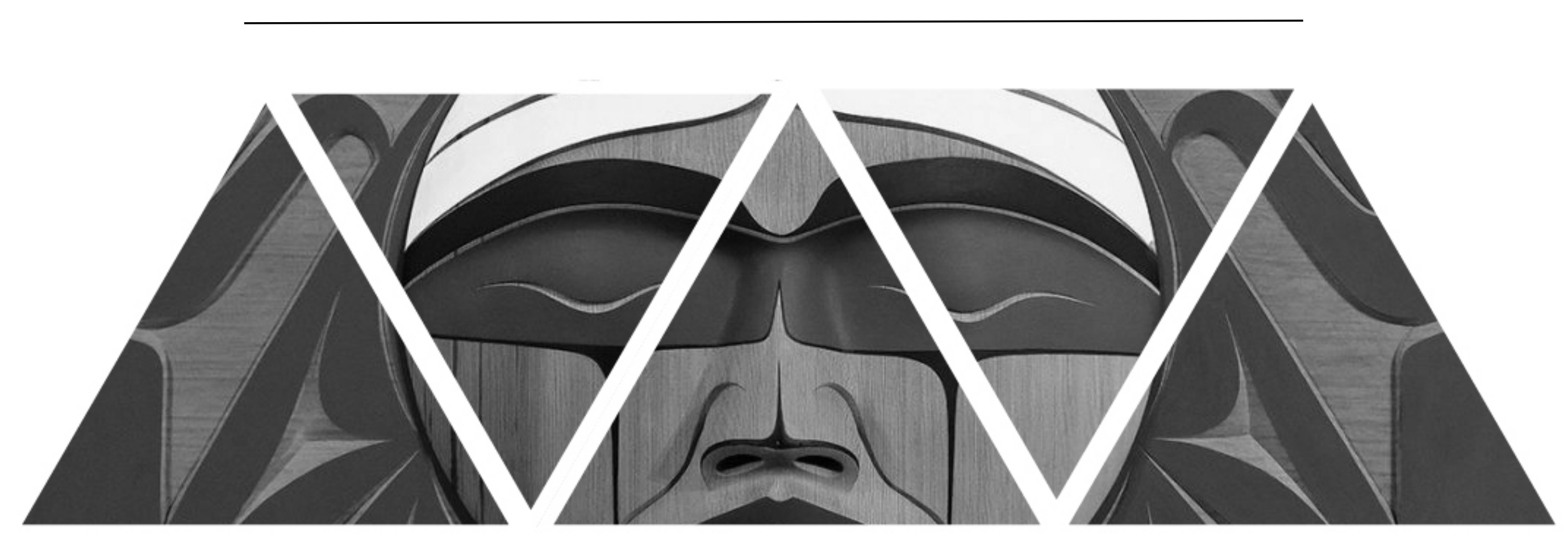

Desmond Wong, Outreach Librarian, University of Toronto Libraries 


\section{SETTLER COLONIALISM}

/'sed(ə)lər,'setlər/ /kə'lōnēəlizəm/

noun

Process of exogenous peoples that replace Indigenous peoples and derive benefit from the theft of lands and resources. 


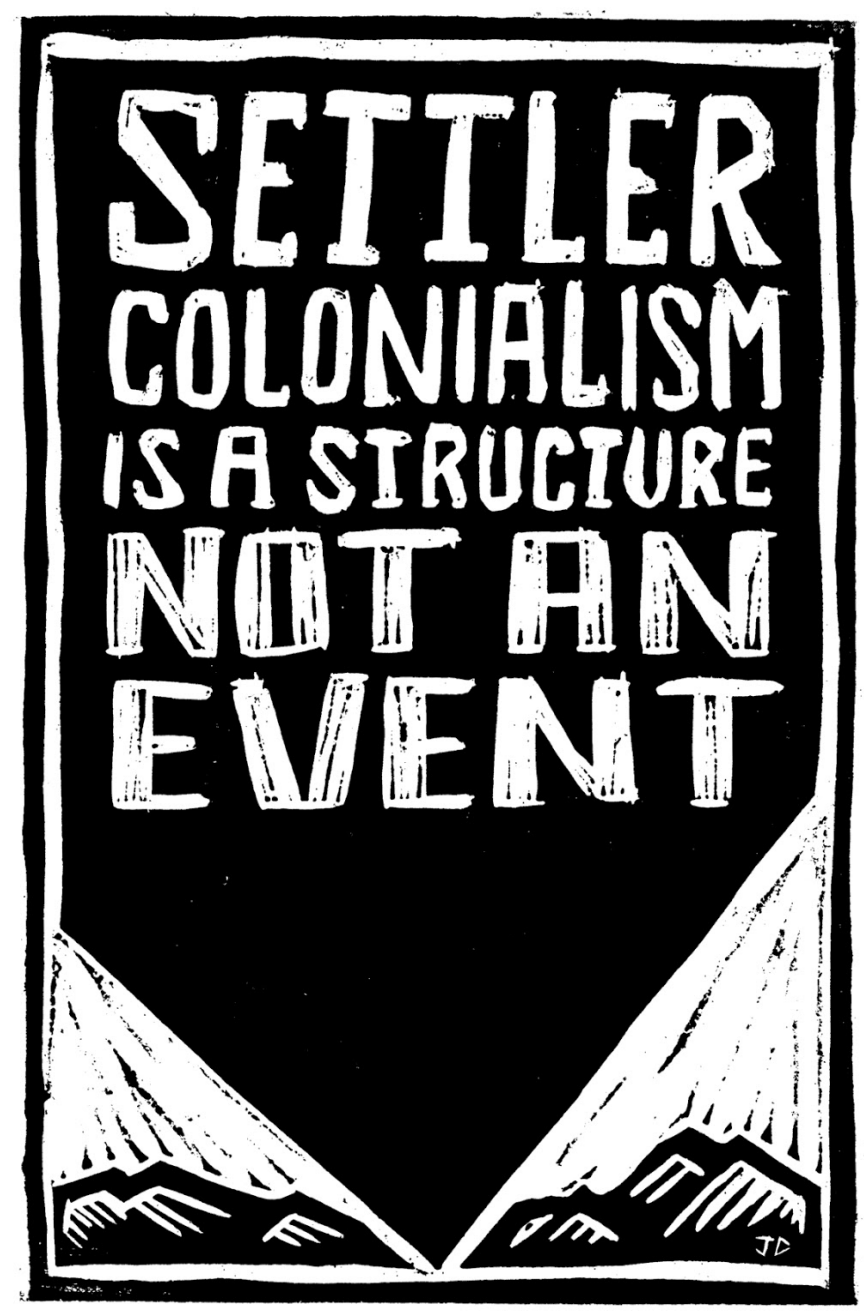




\section{LIBRARY AS A SETTLER COLONIAL INSTITUTION}

- In order to keep expanding, settler colonial institutions must continue to displace Indigenous peoples for their resources

- Physically: Libraries are built on Indigenous lands

- Intellectually: Misrepresentation of Indigenous sovereignties, identities, knowledges

- Historicizing of Indigenous peoples or complete erasure

- Allows settler institutions to separate the actions of colonialism from current reality

- Erasure of modern Indigenous issues affecting Indigenous peoples

- The history of Indigenous peoples in the library is one of erasure and silencing

- Displaces Indigenous knowledges from the Academy

- Considers Indigenous knowledges as primitive or subjective 


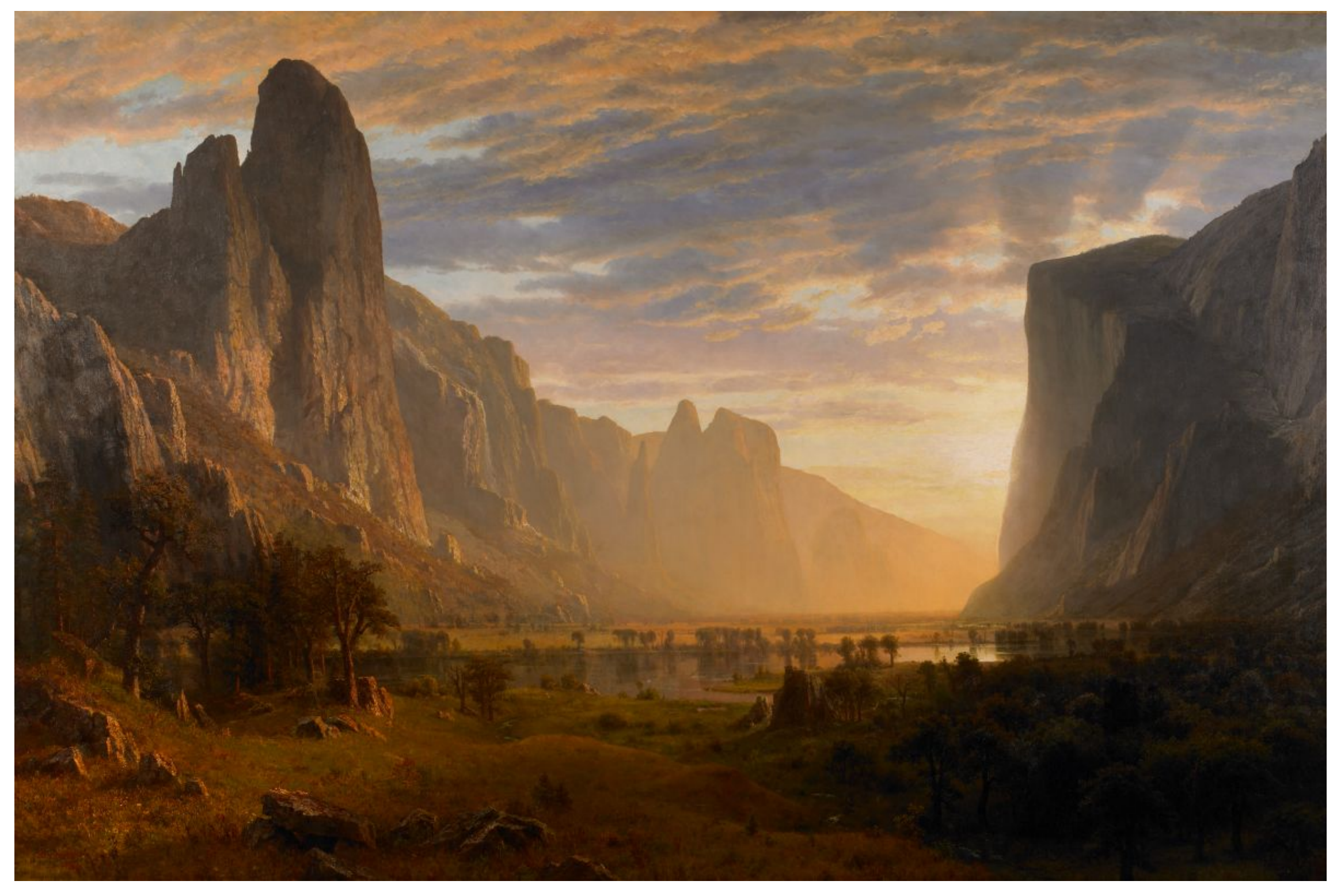




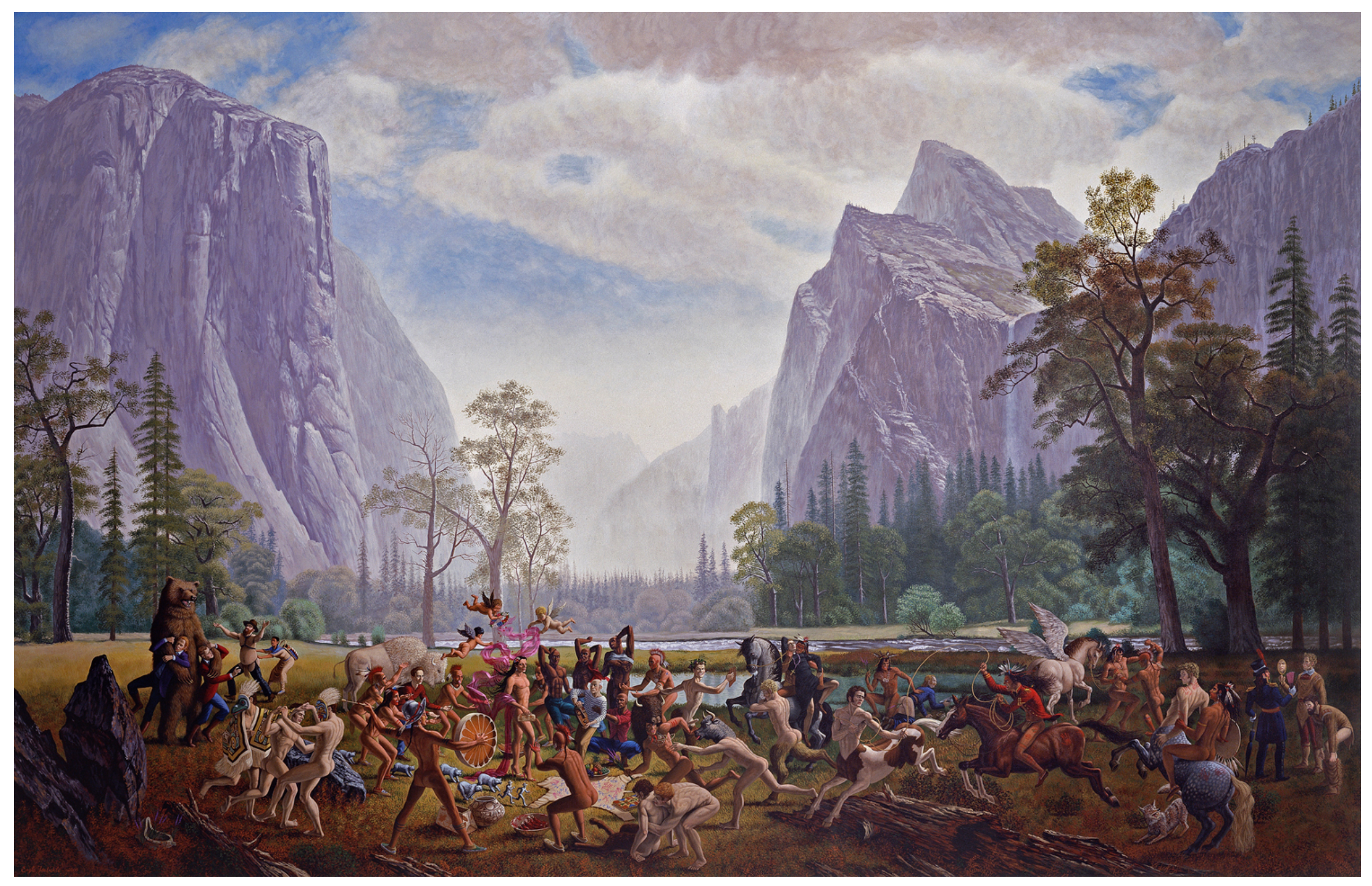




\section{BARRIERS OF INCLUSIVITY}

- Ghettoization of Indigenous materials

- LoC E Class - History of the Americas (E75 - E99)

- LoC F Class - United States, British and Dutch America (Canada), French America, Latin America

- 970/971 in Dewey Decimal Classification

- Settler Colonial Voice

- Library of Congress Subject Heading: Indians of North America/Indians of South America

- Mischaracterization of Indigenous Sovereignties

- Historicism or Exoticism 
Library Catalogue Q Search | Journal Articles |Libraries| Hours| Renew| Help| Contact

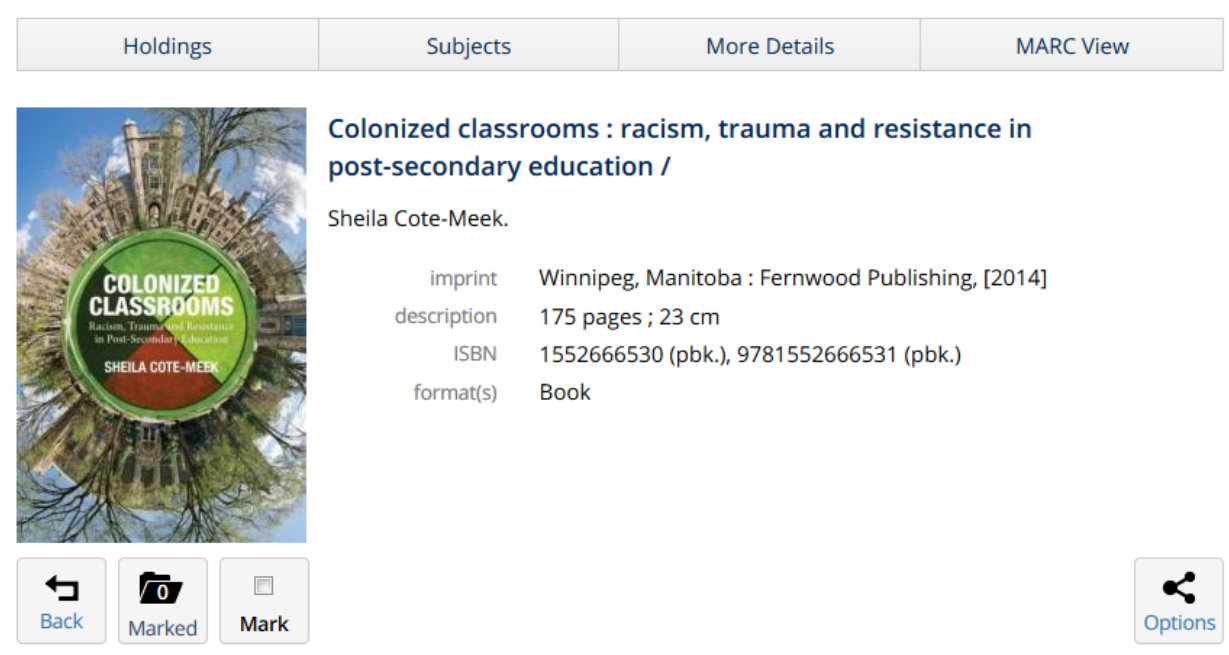

Holdings

$$
\begin{array}{|c|l|l|l|}
\hline \text { In Robarts Stacks E96.2.C68 2014 } & \text { Browse Shelf } & \\
\hline \text { Out University College (Laidlaw) Apr 24, } 2017 \text { E96.2.C68 2014 } & \text { Browse Shelf } \\
\hline
\end{array}
$$

Subjects 


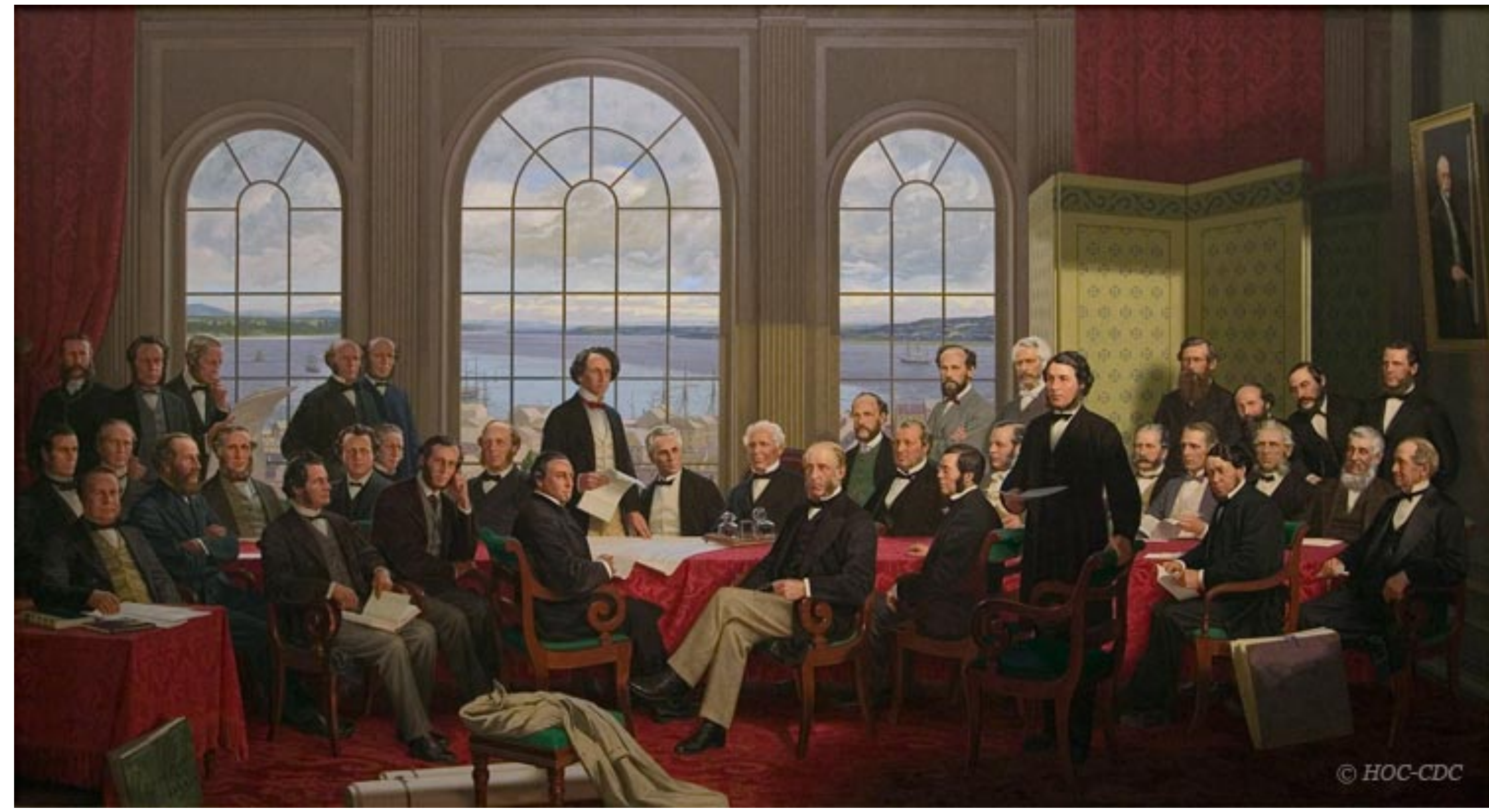




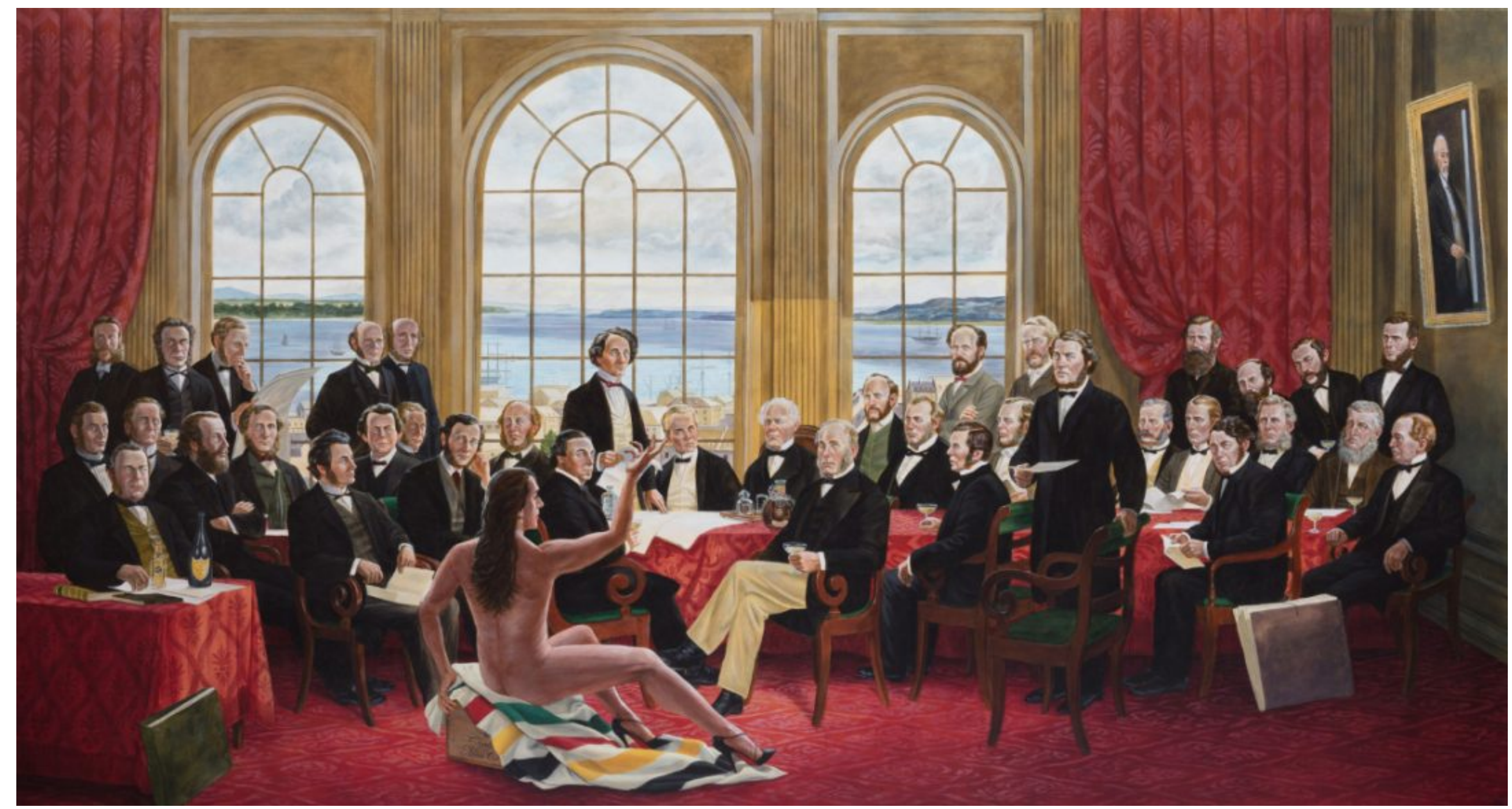




\section{BARRIERS OF INCLUSIVITY}

- Results are violent spaces in our collections, catalogue for our Indigenous patrons

- The lack of integration separates Indigenous knowledges and issues from the larger conversation of scholarship

- Systemic violence built into the fabric of our cataloguing systems

- Lack of Acknowledgement that Indigenous peoples are the original peoples of this Land

- Historical atrocities that took place on this Land are written of as, at worst, a "civilizing force" or in an indifferent lens 


\section{WORK OF AN ALLIED LIBRARIAN}

- In Canada, there was the Truth and Reconciliation Commission regarding the impact of the Indian Residential School System

- Collective goal of the Indian Residential School System was to separate Indigenous children from the influence of their communities and their cultures

- This continues to express itself in intergenerational trauma

- Found that there was a fundamental misunderstanding of Indigenous cultures

- Indigenous issues are everyone's issues

- Create space in:

- our collections for Indigenous knowledges and experiences

- our libraries for Indigenous peoples

- our catalogues to reflect Indigenous worldviews 


\section{LIBRARIANSHIP AS SOLIDARITY}

- At the University of Toronto, the Land is governed by a number of Treaties

- We acknowledge the Indigenous history of the Land upon which the University stands (A land acknowledgement statement)

- Build relationships with the Indigenous communities and work towards goals of reconciliation and decolonization

- Physical, informational and intellectual spaces are created to enable Indigenous knowledges to thrive

- Continue staff development for the learning of Indigenous issues and histories 


\section{LIBRARIANSHIP AS SOLIDARITY}

- Who are you?

- Where are you from?

- What is your relationship to the Land?

- What are your responsibilities to the Indigenous people of your territory?

- What is your guest obligation? 


\section{RECOMMENDED RESOURCES}

Devon, A. M., \& Wilson, A. C. (2004). Indigenizing the academy: Transforming scholarship and empowering communities. Lincoln: University of Nebraska Press.

Dunbar-Ortiz, R. (2014). An Indigenous Peoples' History of the United States. Boston, MA: Beacon Press.

Lee, D. (2008). Indigenous Knowledges and the University Library. Canadian Journal of Native Education, 31(1), 149161-321.

Lee, D. (2011). Indigenous Knowledge Organization: A Study of Concepts, Terminology, Structure and (Mostly) Indigenous Voices. Partnership: The Canadian Journal of Library and Information Practice and Research, 6(1). https://doi.org/10.21083/partnership.v6i1.1427

Tuck, E., \& Yang, K. W. (2012). Decolonization is not a metaphor. Decolonization: Indigeneity, Education \& Society, 1(1). Retrieved from: http://decolonization.org/index.php/des/article/view/18630

Kirkness, V. J., \& Barnhardt, R. (1991). First Nations and higher education: The four R's-respect, relevance, reciprocity, responsibility. Journal of American Indian Education, 30(3), 1-15. 


\section{References}

Bierstadt, Albert. (1865). Looking Down Yosemite Valley. [Oil on Canvas]. Birmingham Museum.

Davidson, Jared. (2015). Settler Colonialism is a Structure not an Event. [Digital woodcut]. Garage Collective. Retrieved from: http://garagecollective.blogspot.ca/2015/04/settler-colonialism-is-structure-not.html

Devon, A. M., \& Wilson, A. C. (2004). Indigenizing the academy: Transforming scholarship and empowering communities. Lincoln: University of Nebraska Press.

Dunbar-Ortiz, R. (2014). An Indigenous Peoples' History of the United States. Boston, MA: Beacon Press.

Lee, D. (2008). Indigenous Knowledges and the University Library. Canadian Journal of Native Education, 31(1), 149-161-321.

Lee, D. (2011). Indigenous Knowledge Organization: A Study of Concepts, Terminology, Structure and (Mostly) Indigenous Voices. Partnership: The Canadian Journal of Library and Information Practice and Research, 6(1). https://doi.org/10.21083/partnership.v6i1.1427

Tuck, E., \& Yang, K. W. (2012). Decolonization is not a metaphor. Decolonization: Indigeneity, Education \& Society, 1(1). Retrieved from: http://decolonization.org/index.php/des/article/view/18630

Kirkness, V. J., \& Barnhardt, R. (1991). First Nations and higher education: The four R's-respect, relevance, reciprocity, responsibility. Journal of American Indian Education, 30(3), 1-15.

Monkman, Kent. (2007). Triumph of Mischief. [Oil on Canvas]. National Gallery of Canada.

Monkman, Kent. (2010). The Daddies. [Oil on Canvas]. National Gallery of Canada.

Olson, H. A., \& Schlegl, R. (2001). Standardization, Objectivity, and User Focus: A Meta-Analysis of Subject Access Critiques. Cataloging \& Classification Quarterly, 32(2), 61-80. https://doi.org/10.1300/J104v32n02_06

Vowel, C. (2016). Indigenous writes: a guide to First Nations, Métis \& Inuit issues in Canada.

Woods, Rex. (1968). Fathers of Confederation. [Oil on Canvas]. House of Commons Galleries. 


\section{CONTACT}

\section{de.wong@utoronto.ca}

@desmondcwong 